\title{
Use of Green Fluorescent Protein to Detect Expression of nif Genes of Azoarcus sp. BH72, a Grass-Associated Diazotroph, on Rice Roots
}

\author{
Tanja Egener, Thomas Hurek, and Barbara Reinhold-Hurek \\ Max-Planck-Institut für terrestrische Mikrobiologie, Arbeitsgruppe Symbioseforschung, Karl-von-Frisch-Str., \\ D-35043 Marburg, Germany \\ Accepted 24 September 1997.
}

\begin{abstract}
A $g f p$ (green fluorescent protein) cassette for transcriptional fusions has been developed to study gene expression in Azoarcus sp. BH72 in association with plant roots. The bacteria expressed nitrogenase genes (nifHDK) in the rhizosphere, on root tips, and in epidermal cells of rice seedlings. Green fluorescent protein fusions also visualized promoter activity of single cells in soil.
\end{abstract}

Additional keywords: nitrogen fixation.

A variety of nitrogen-fixing bacteria such as Azospirillum spp. (Tarrand et al. 1978), Herbaspirillum spp. (Baldani et al. 1996), Acetobacter diazotrophicus (Gillis et al. 1989), and Azoarcus spp. (Reinhold-Hurek et al. 1993), occur on or in roots of grasses, some even endophytically inside roots and stems (James et al. 1994; Hurek et al. 1994b). Most Azoarcus spp. were isolated from Kallar grass (Leptochloa fusca (L.) Kunth) (Reinhold-Hurek et al. 1993; Hurek and ReinholdHurek 1995), a pioneer plant grown on salt-affected, lowfertility soils in the Punjab of Pakistan (Sandhu and Malik 1975). Azoarcus sp. BH72 can colonize and invade roots of Kallar grass and rice seedlings in similar patterns in gnotobiotic culture, without causing symptoms of plant disease despite the endophytic growth (Hurek et al. 1994b). Recently, we have obtained evidence that an Azoarcus sp. occurs naturally in association with rice roots (Hurek et al. 1997). The colonization of rice roots is of special interest, since rice is an agriculturally important crop that may provide microaerobic niches for nitrogen fixation when grown under flooded conditions. Low $\mathrm{O}_{2}$ concentrations are essential for $\mathrm{N}_{2}$ fixation by the strictly respiratory Azoarcus spp. (Hurek et al. 1987). At extremely low $\mathrm{O}_{2}$ concentrations (30 nM), Azoarcus sp. BH72 can develop into a hyperinduced state, which is characterized by augmented rates and efficiencies of $\mathrm{N}_{2}$ fixation (Hurek et al. 1994a, 1995).

Positive effects of diazotrophs such as Azospirillum spp. on yield of gramineous plants have largely been attributed to bacterial phytohormones rather than to nitrogen fixation

Corresponding author: B. Reinhold-Hurek;

Telephone: (49) 6421-178101; Fax: (49) 6421-178109;

E-mail: reinhold@mailer.uni-marburg.de
(Okon and Labandera-Gonzalez 1994). However, nitrogen fixation may significantly contribute to plant nutrition in gramineous systems, as has been shown for several sugar cane cultivars in Brazil (Lima et al. 1987). Since gramineous plants do not form nitrogen-fixing symbiotic structures such as root nodules, it is crucial for an understanding of the mechanisms of interactions to know sites of bacterial colonization and expression of bacterial genes, especially structural genes of nitrogenase nifHDK.

Bacterial gene expression on or in plant roots can be visualized with transcriptional fusions of bacterial target genes to reporter genes. Recently, the jellyfish green fluorescent protein (GFP) has been introduced as a marker for gene expression (Chalfie et al. 1994). Advantages of this reporter system are that external substrates or co-factors are not required, and diffusible products of an enzyme reaction are not involved. Since gene expression can be monitored and reliably localized in vivo without damage of the tissue, GFP appears to be a promising reporter system to study plant-microbe interactions. It was applied under control of a constitutive promoter to visualize rhizobia (Gage et al. 1996). However, to our knowledge, the GFP has not been used for measurement of bacterial gene regulation in association with plants. In this study, we report the construction of a promoterless $g f p$ gene cassette for transcriptional fusions and its suitability to study expression of nitrogenase genes of Azoarcus sp. $\mathrm{BH} 72$ in association with rice roots.

A $g f p$ cassette for transcriptional fusions in Azoarcus sp. BH72 was constructed as follows. Translational stop signals in all three reading frames (bold, see below) were introduced by polymerase chain reaction (PCR) upstream of a consensus sequence of the putative ribosomal binding site of Azoarcus sp. BH72 nif genes (underlined), which was fused to the start codon of $g f p$ (italics); the cassette was flanked by EcoRI restriction sites (double underlined). A $g f p$ mutant was used that shows increased fluorescence, stability, and a red shift in the excitation wavelength due to an F64L, S65T double substitution (Cormack et al. 1996). It was amplified with PCR primers binding to the $5^{\prime}$-end (5'-GGAATTCTGATTGATTGA GGAGAGTTTCAACATGAGTAAAGGAGAAGAACTT-3' ) and the $3^{\prime}$-end (5'-GGAATTCAATTGGAAGTCTGGACAT TT-3') of $g f p$. The PCR fragment was cloned into the EcoRI 
restriction site of the plasmid pSK Bluescript (Stratagene, La Jolla, CA) under the control of the lacZ promoter in Escherichia coli $\mathrm{DH} 5 \alpha$. For a transcriptional fusion with nifH, a 1.45-kb EcoRI-HindIII fragment of pBGVN3 (Hurek et al. 1995) carrying $800 \mathrm{bp}$ of the nifH gene and 640 bp of upstream sequences, including a $\sigma^{54}$-type promoter sequence, was cloned into pUC18, resulting in pEN322. The $g f p$ cassette was inserted into the EcoRI site of the nifH gene in pEN322, and this construct was integrated into the chromosome of Azoarcus sp. BH72 (Reinhold et al. 1986; Reinhold-Hurek et al. 1993) by homologous recombination after electroporation (Fig. 1A), resulting in the mutant strain Azoarcus sp. BHFN35.

Bacteria were grown in VM medium (Reinhold-Hurek et al. 1993) for electroporation, and in SM medium (Reinhold et al. 1985) as inoculum for plant experiments. Nitrogen-fixing cells were grown in liquid nitrogen-free SM medium in gas-tight, stoppered flasks under a reduced-oxygen atmosphere (Karg and Reinhold-Hurek 1996). Rice seeds (Oryza sativa var. nihonnbare) were surface sterilized, grown in agar medium, and inoculated as previously described (Hurek et al. 1994b), except that no proline and only $5 \mathrm{mg}$ of malate per liter were added to the plant growth medium. Alternatively, a nonsterile, dried saline-sodic soil from a Kallar grass field in Shakot, Pakistan, was saturated with sterile, bi-distilled water and inoculated with $10^{9}$ bacteria per $5 \mathrm{ml}$ of soil. To visualize fluorescence of roots or bacteria, samples were incubated under oxic conditions at $4^{\circ} \mathrm{C}$ for 1 to $2 \mathrm{~h}$ to allow the formation of the GFP chromophore (Cody et al. 1993), and then inspected with a Zeiss Axioplan 2 microscope with a band pass excitation filter BP450-490, a 510 dichromatic beam splitter, and a barrier emission filter LP520. Micrographs were recorded on a Kodak Ectachrome 64 film, or by a 3 Chip RGB Colour Camera (Hamamatsu Photonic Systems, Bridgewater, NJ). Digital confocal imaging was achieved with Improvision Openlab software (Improvision, Coventry, England). Quantification of fluorescence in suspended cells was carried out in a Fluorolite 1000 fluorometer (Dynatech, Denkendorf, Germany).

When wild-type GFP (Chalfie et al. 1994) or a GFP mutant with a single amino acid substitution (Heim et al. 1994) were expressed in Azoarcus sp. BH72, no significant fluorescence was observed (not shown). In contrast, a GFP mutant that carries a double amino acid substitution and shows increased fluorescence (Cormack et al. 1996) yielded sufficient light emission to visualize gene expression in single cells of Azoarcus sp. BH72 (Fig. 1C). The nonefficient variants have been used successfully in mycobacteria (Kremer et al. 1995), Bacillus subtilis (Webb et al. 1997), and Rhizobium meliloti (Gage et al. 1996); thus, the application of GFP in new bacterial species requires careful optimizing. Lack of sufficient fluorescence might be due to mRNA instability or to inefficient folding or chromophore formation of the protein. Multiple copies of $g f p$ on plasmids might increase the yield of fluorescence; however, our strategy was to use a single gene copy integrated into the bacterial chromosome to allow long-term experiments without application of selective antibiotics. The fluorescence obtained by the transcriptional fusion of $g f p$ to the nifH promoter correlated well with nifH gene expression. Bright fluorescence was observed only in exponentially grown cells that had high rates of nitrogen fixation (acetylene reduction) (Fig. $1 \mathrm{~B}, \mathrm{C}, 18 \mathrm{~h}$ ) and thus high expression levels of nif genes. Otherwise, fluorescence faded within a few seconds (Fig. 1C, 12 h, 38 h), or no fluorescence was detected in the stationary phase (Fig. 1C, $46 \mathrm{~h}$ ) or under conditions of repression of nif genes (aerobic growth on ammonia; Fig. 1C, $0 \mathrm{~h}$ ). The repression of the nif-gfp fusion was confirmed by quantification of fluorescence in bacterial suspensions. Azoarcus sp. BHFN35 grown on ammonia $(0.1 \%)$ showed the background levels of fluorescence of the $g f p$-lacking wild-type strain, whereas nitrogen-fixing cells (Fig. 1B, 18 h) showed 1,167 units per $\mathrm{OD}_{578}=1$. This repression by combined nitrogen under free-living conditions was also observed when bacteria were grown in association with plants in the presence of $\mathrm{KNO}_{3}(0.1 \%)$.

It is difficult to assess cellular gene expression in soil with transcriptional fusions, because some soil microorganisms show background activity of most of the commonly used reporter proteins, such as $\beta$-glucuronidase (Jefferson et al. 1987). Moreover, detection levels are not sufficient to allow visualizing of single cells, e.g., for luciferase (Kloepper and
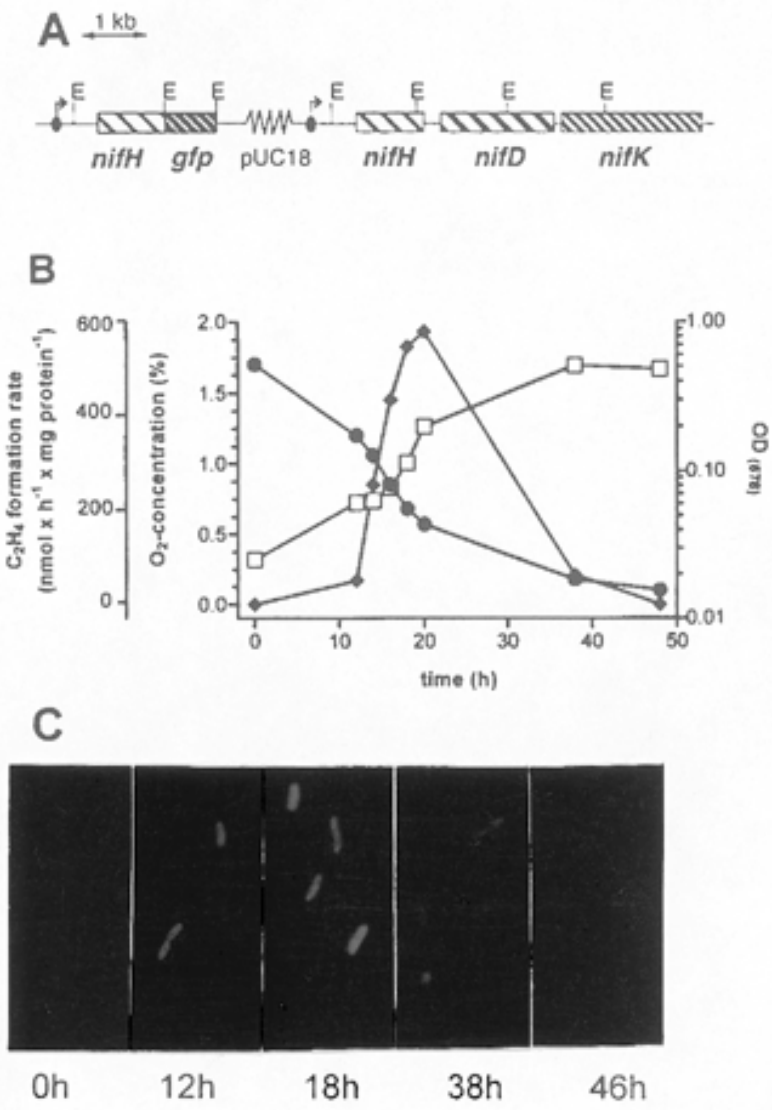

Fig. 1. Expression of a nifH-gfp fusion in nitrogen-fixing Azoarcus sp. strain BHGN35. A, Physical map of the integration into the chromosome of a pUC18-derived plasmid carrying a nifH-gfp fusion. The fusion and the uninterrupted nifHDK operon are under the control of the original $\sigma^{54}$-type promoter. E, EcoRI restriction site. B, Growth (open square, $\mathrm{OD}_{578}$ ) and specific acetylene reduction rate (solid diamond) of an $\mathrm{N}_{2}$ fixing culture under reduced-oxygen atmosphere (solid circle, $\mathrm{O}_{2}$ concentration in headspace). C, In vivo green fluorescent protein (GFP) fluorescence of cells sampled at different points of the growth curve when nitrogen fixation rates were absent $(0 \mathrm{~h})$, low $(12 \mathrm{~h})$, high $(18 \mathrm{~h})$ or ceased in stationary phase $(38 \mathrm{~h}, 46 \mathrm{~h})$; for comparison, epifluorescence micrographs were taken with identical exposure times. 

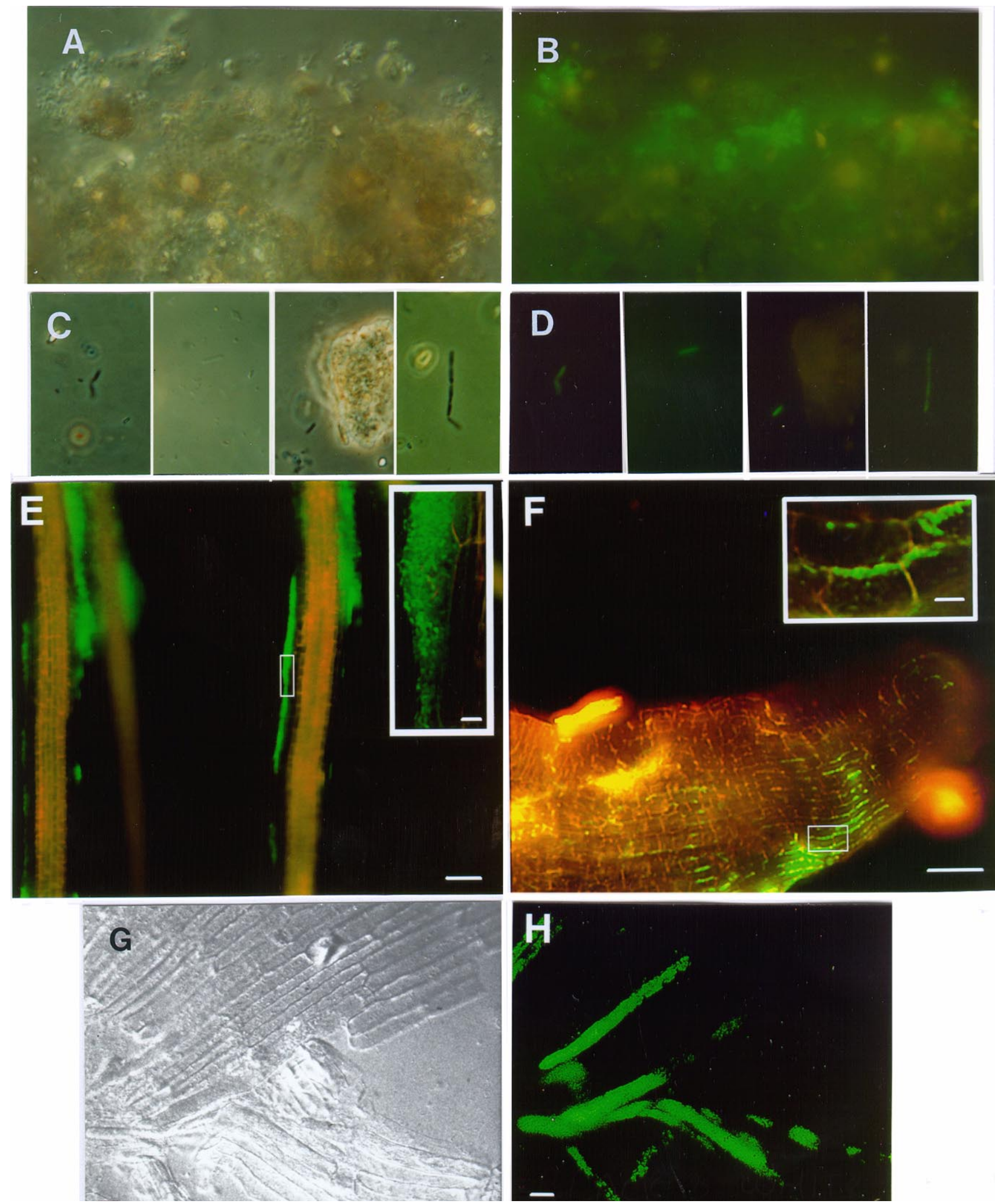

Fig. 2. Expression of a nifH-gfp fusion of Azoarcus sp. strain BHGN35 in soil (A-D) and in association with roots of rice seedlings (E-H) 5 or 10 days after inoculation, respectively. Light and corresponding epifluorescence micrographs of soil-bacterial aggregates $(\mathbf{A}, \mathbf{B})$, or single bacteria $(\mathbf{C}$, D) in wet soil showing green fluorescent protein (GFP) fluorescence. Digital confocal images of (E), layers of bacterial cells attached to lateral roots $(\mathbf{F})$, fluorescing bacteria attached to the elongation/differentiation zone of a root tip, and $(\mathbf{G}, \mathbf{H})$, fluorescing bacteria inside a layer of root cap cells that were sloughed off for microscopy. Digital confocal images are composed of one (E, H) or $60(\mathbf{F})$ optical sections. Boxed regions at higher magnification show single fluorescing bacteria. Corresponding light micrographs $(\mathbf{A}, \mathbf{C}, \mathbf{G})$ are with interference-contrast or phase-contrast illumination. Bars $=100 \mu \mathrm{m}$ or $5 \mu \mathrm{m}$ in box $(\mathbf{E}), 100 \mu \mathrm{m}$ or $10 \mu \mathrm{m}$ in box $(\mathbf{F})$, or $10 \mu \mathrm{m}(\mathbf{H})$. 
Beauchamp 1992). On the other hand, the GFP might be a promising alternative. We were able to detect nifH-gfp expression in single cells (Fig. 2D) and in soil-bacterial aggregates (Fig. 2B) in an unsterile, sandy-clay loam inoculated with Azoarcus sp. BHFN35, the blue-green GFP fluorescence being clearly distinct from yellow-green background fluorescence of soil particles. There was no background activity from soil-inhabiting microorganisms, blue-green fluorescing bacteria being undetectable in uninoculated controls (not shown). Therefore, this method could be useful to track bacteria, e.g., genetically engineered microorganisms, or to analyze gene expression and its spatial distribution in complex, heterogeneous soil systems. The potential of GFP to monitor bacteria in quartz sand (Burlage et al. 1996) or in other environments such as activated sludge (Eberl et al. 1997) or aquatic environments (Leff and Leff 1996) has been demonstrated.

nif gene expression of Azoarcus sp. BH72 was also visualized in association with roots of rice seedlings, indicating that the rice rhizosphere may provide suitable conditions for $\mathrm{N}_{2}$ fixing Azoarcus spp. even when only negligible amounts of carbon source $(5 \mathrm{mg}$ per liter) were added. The autofluorescence of roots themselves was yellowish and clearly distinct from blue-green GFP fluorescence (Fig. 2E,F). Strong fluorescence was found in bacterial aggregates adjacent to lateral roots, thick layers being visible when the agar matrix was still attached (Fig. 2E). gfp-expressing bacteria were also tightly adhered above root tips at the zone of elongation and differentiation (Fig. 2F). This correlates with the observation that this zone is the site of primary colonization and infection of Kallar grass and rice roots (Hurek et al. 1994b). Occasionally, root epidermis cells were filled with tightly packed, fluorescing bacteria (Fig. 2G,H), indicating that nif genes can be expressed even when bacteria are inside plant cells. These plant cells are most likely degenerated (Hurek et al. 1994b); however, plant cell content of combined nitrogen does not appear to repress bacterial nif genes. The nifH expression has also been observed for Azospirillum brasilense on the surface of wheat roots with lacZ (Arsène et al. 1994) and gus fusions (Vande Broek et al. 1993); expression was reported to be rare without addition of external carbon sources or reduced oxygen concentrations (Vande Broek et al. 1993). Transcriptional gfp fusions have two advantages: (i) since the signal is the fluorescence of the cellular protein itself and is thus not diffusible, in contrast to the primary product of X-Gal or X-Glu staining, the site of expression can be unequivocally localized; and (ii) only strong gene expression can be visualized in Azoarcus sp. BHGN35 (Fig. 1), assuring that the signal is significant and not due to an accumulation of cleaved substrate during a long incubation period, which may still be obtained at low gene expression levels.

Thus, the application of the transcriptional $g f p$ fusions developed here may contribute to an understanding of functions and dynamics of plant-microbe interactions.

\section{ACKNOWLEDGMENTS}

We thank R. Tsien, D. C. Prasher, and S. Falkow for $g f p$-containing plasmids, and Matthias Ullrich for use of the fluorometer. This work was supported by a grant of the Deutsche Forschungsgemeinschaft (Re756/51) to B. R.-H.

\section{LITERATURE CITED}

Arsène, F., Katupitiya, S., Kennedy, I. R., and Elmerich, C. 1994. Use of lacZ fusions to study the expression of nif genes of Azospirillum brasilense in association with plants. Mol. Plant-Microbe Interact. 7:748757.

Baldani, J. I., Pot, B., Kirchhof, G., Falsen, E., Baldani, V. L. D., Olivares, F. L., Hoste, B., Kersters, K., Hartmann, A., Gillis, M., and Döbereiner, J. 1996. Emended description of Herbaspirillum: Inclusion of [Pseudomonas] rubrisubalbicans, a mild plant pathogen, as Herbaspirillum rubrisubalbicans comb. nov., and classification of a group of clinical isolates (EF Group 1) as Herbaspirillum species 3. Int. J. Syst. Bacteriol. 46:802-810.

Burlage, R. S., Yang, Z. K., and Mehlhorn, T. 1996. A transposon for green fluorescent protein transcriptional fusions: Application for bacterial transport experiments. Gene 173:53-58.

Chalfie, M., Tu, Y., Euskirchen, G., Ward, W. W., and Prasher, D. C. 1994. Green fluorescent protein as a marker for gene expression. Science 263:802-805.

Cody, C. W., Prasher, D. C., Westler, W. M., Prendergast, F. G., and Ward, W. W. 1993. Chemical structure of the hexapeptide chromophore of the Aequorea green-fluorescent protein. Biochemistry 32: 1212-1218.

Cormack, B. P., Valdivia, R. H., and Falkow, S. 1996. FACS-optimized mutants of the green fluorescent protein (GFP). Gene 173:33-38.

Eberl, L., Schulze, R., Ammendola, A., Geisenberger, O., Erhart, R., Sternberg, C., Molin, S., and Amann, R. 1997. Use of green fluorescent protein as a marker for ecological studies of activated sludge communities. FEMS Microbiol. Lett. 149:77-83.

Gage, D. J., Bobo, T., and Long, S. R. 1996. Use of green fluorescent protein to visualize the early events of symbiosis between Rhizobium meliloti and alfalfa (Medicago sativa). J. Bacteriol. 178:7159-7166.

Gillis, M., Kersters, K., Hoste, B., Janssens, D., Kroppenstedt, R. M., Stephan, M. P., Teixeira, K. R. S., Doebereiner, J., and De Ley, J. 1989. Acetobacter diazotrophicus sp. nov., a nitrogen-fixing acetic acid bacterium associated with sugar cane. Int. J. Syst. Bacteriol. 39: 361-364.

Heim, R., Prasher, D. C., and Tsien, R. Y. 1994. Wavelength mutations and posttranslational autoxidation of green fluorescent protein. Proc. Natl. Acad. Sci. USA 91:12501-12504.

Hurek, T., Egener, T., and Reinhold-Hurek, B. 1997. Divergence in nitrogenases of Azoarcus spp., Proteobacteria of the $\beta$-subclass. J. Bacteriol. 179:4172-4178.

Hurek, T., Reinhold, B., Fendrik, I., and Niemann, E. G. 1987. Rootzone-specific oxygen tolerance of Azospirillum spp. and diazotrophic rods closely associated with Kallar grass. Appl. Environ. Microbiol. 53:163-169.

Hurek, T., and Reinhold-Hurek, B. 1995. Identification of grassassociated and toluene-degrading diazotrophs, Azoarcus spp., by analyses of partial $16 \mathrm{~S}$ ribosomal DNA sequences. Appl. Environ. Microbiol. 61:2257-2261.

Hurek, T., Reinhold-Hurek, B., Turner, G. L., and Bergersen, F. J. 1994a. Augmented rates of respiration and efficient nitrogen fixation at nanomolar concentrations of dissolved $\mathrm{O}_{2}$ in hyperinduced Azoarcus sp. strain BH72. J. Bacteriol. 176:4726-4733.

Hurek, T., Reinhold-Hurek, B., Van Montagu, M., and Kellenberger, E. 1994b. Root colonization and systemic spreading of Azoarcus sp. strain BH72 in grasses. J. Bacteriol. 176:1913-1923.

Hurek, T., Van Montagu, M., Kellenberger, E., and Reinhold-Hurek, B. 1995. Induction of complex intracytoplasmic membranes related to nitrogen fixation in Azoarcus sp. BH72. Mol. Microbiol. 18:225-236.

James, E. K., Reis, V. M., Olivares, F. L., Baldani, J. I., and Döbereiner, J. 1994. Infection of sugar cane by the nitrogen-fixing bacterium Acetobacter diazotrophicus. J. Exp. Bot. 45:757-766.

Jefferson, R. A., Kavanagh, T. A., and Bevan, M. W. 1987. GUS fusions: $\beta$-glucuronidase as a sensitive and versatile gene fusion marker in higher plants. EMBO J. 6:3901-3908.

Karg, T., and Reinhold-Hurek, B. 1996. Global changes in protein composition of $\mathrm{N}_{2}$-fixing Azoarcus sp. strain BH72 upon diazosome formation. J. Bacteriol. 178:5748-5754.

Kloepper, J. W., and Beauchamp, C. J. 1992. A review of issues related to measuring colonization of plant roots by bacteria. Can. J. Microbiol. 38:1219-1232.

Kremer, L., Baulard, A., Estaquier, J., Poulain-Godefroy, O., and Locht, C. 1995. Green fluorescent protein as a new expression marker in my- 
cobacteria. Mol. Microbiol. 17:913-922.

Leff, L. G., and Leff, A. A. 1996. Use of green fluorescent protein to monitor survival of genetically engineered bacteria in aquatic environments. Appl. Environ. Microbiol. 62:3486-3488.

Lima, E., Boddey, R. M., and Döbereiner, J. 1987. Quantification of biological nitrogen fixation associated with sugar cane using a ${ }^{15} \mathrm{~N}$ aided nitrogen balance. Soil Biol. Biochem. 19:165-170.

Okon, Y., and Labandera-Gonzalez, C. A. 1994. Agronomic applications of Azospirillum - an evaluation of 20 years worldwide field inoculation. Soil Biol. Biochem. 26:1591-1601.

Reinhold, B., Hurek, T., and Fendrik, I. 1985. Strain-specific chemotaxis of Azospirillum spp. J. Bacteriol. 162:190-195.

Reinhold, B., Hurek, T., Niemann, E.-G., and Fendrik, I. 1986. Close association of Azospirillum and diazotrophic rods with different root zones of Kallar grass. Appl. Environ. Microbiol. 52:520-526.

Reinhold-Hurek, B., Hurek, T., Gillis, M., Hoste, B., Vancanneyt, M., Kersters, K., and De Ley, J. 1993. Azoarcus gen. nov., nitrogenfixing proteobacteria associated with roots of Kallar grass
(Leptochloa-fusca (L.) Kunth) and description of two species Azoarcus indigens sp. nov. and Azoarcus communis sp. nov. Int. J. Syst. Bacteriol. 43:574-584.

Sandhu, G. R., and Malik, K. A. 1975. Plant succession - A key to the utilization of saline soils. Nucleus 12:35-38.

Tarrand, J. J., Krieg, N. R., and Döbereiner, J. 1978. A taxonomic study of the Spirillum lipoferum group, with description of a new genus, Azospirillum gen. nov. and two species, Azospirillum lipoferum (Beijerinck) comb. nov. and Azospirillum brasilense sp. nov. Can. J. Microbiol. 24:967-980.

Vande Broek, A., Michiels, J., Van Gool, A., and Vanderleyden, J. 1993. Spatial-temporal colonization patterns of Azospirillum brasilense on the wheat root surface and expression of the bacterial nifH gene during association. Mol. Plant-Microbe Interact. 6:592-600.

Webb, C. D., Teleman, A., Gordon, S., Straight, A., Belmont, A., Lin, D. C. H., Grossman, A. D., Wright, A., and Losick, R. 1997. Bipolar localization of the replication origin regions of chromosomes in vegetative and sporulating cells of $B$. subtilis. Cell 88:667-675. 